\title{
AN AMARAVATI-SCHOOL PILLAR FROM THE RIJKSMUSEUM: STYLE AND ATTRIBUTION
}

Archaeological remains of Buddhist monuments in Andhra Pradesh often travelled a long way before reaching Europe or America. Paucity of information on provenances frequently led to the incorrect identification of Andhra pieces, with most being ascribed to Amaravati, the most renowned Andhran Buddhist site. This identification, in many cases, proved wrong.

The Rijksmuseum's collection of Indian art contains a pillar fragment 'in the Amaravati style' (figs. I-3). It was bought in 1955 by the Asian Art Society in the Netherlands (VVAK). It has long been thought that the sculpture came from Amaravati proper. However, in view of the recent scholarship on the early Buddhist sites in Andhra, I believe this attribution should be reconsidered.

\section{Comparison: the garland motif}

Considering the style, the decorative motifs and the material used, there can be no doubt that the pillar fragment does indeed belong to the so-called Amaravati School of art. But which among the numerous Andhran sites would have produced it? There are over I40 early historic sites (ca. 300 BCE-30o CE) ${ }^{1}$ in the entire Andhra region, many of them Buddhist, and new ones are still being discovered. Yet, in spite of a comprehensive search, I did not encounter a pillar resembling the one discussed here. ${ }^{2}$

Although the motif of garland and garland-bearers is quite widespread in Amaravati art, it seems to have never been used on a pillar. In the early phase of Amaravati (ca. 50-I BCE) undulating garlands carried by ganas ('dwarves') decorated the inner face of a rail coping. ${ }^{3}$ These carvings, however, are rather shallow, and the hairstyles and postures of the dwarves differ widely from those on the Rijksmuseum fragment. Besides, the garland is much more schematic and the area above the lower bends is filled with large half-lotuses seen from above, resembling those frequently depicted on rail pillars.

After the early period the garland-bearing dwarves seem to have been replaced by running youths. ${ }^{4}$ The garland became much more elaborate and the composition more complex, showing the horror vacui that characterises mature Amaravati art. All these friezes seem even more removed from that on the pillar under discussion than those belonging to the first phase. 


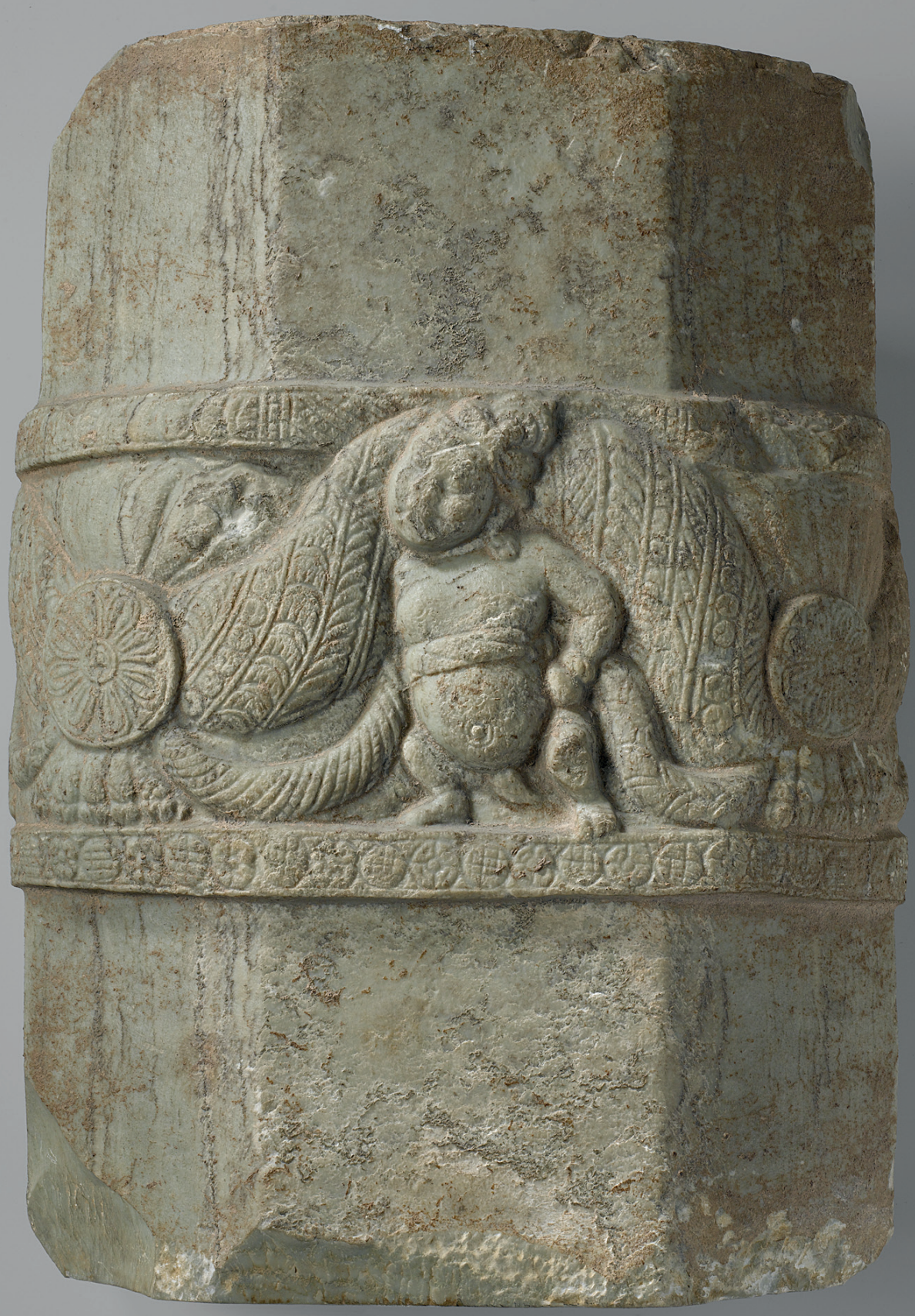

Fig. 1

Pillar fragment, limestone,

$48 \times 34 \times 17 \mathrm{~cm}$, India,

3rd century, Rijksmuseum,

Amsterdam, inv.no. AK-MAK-304 

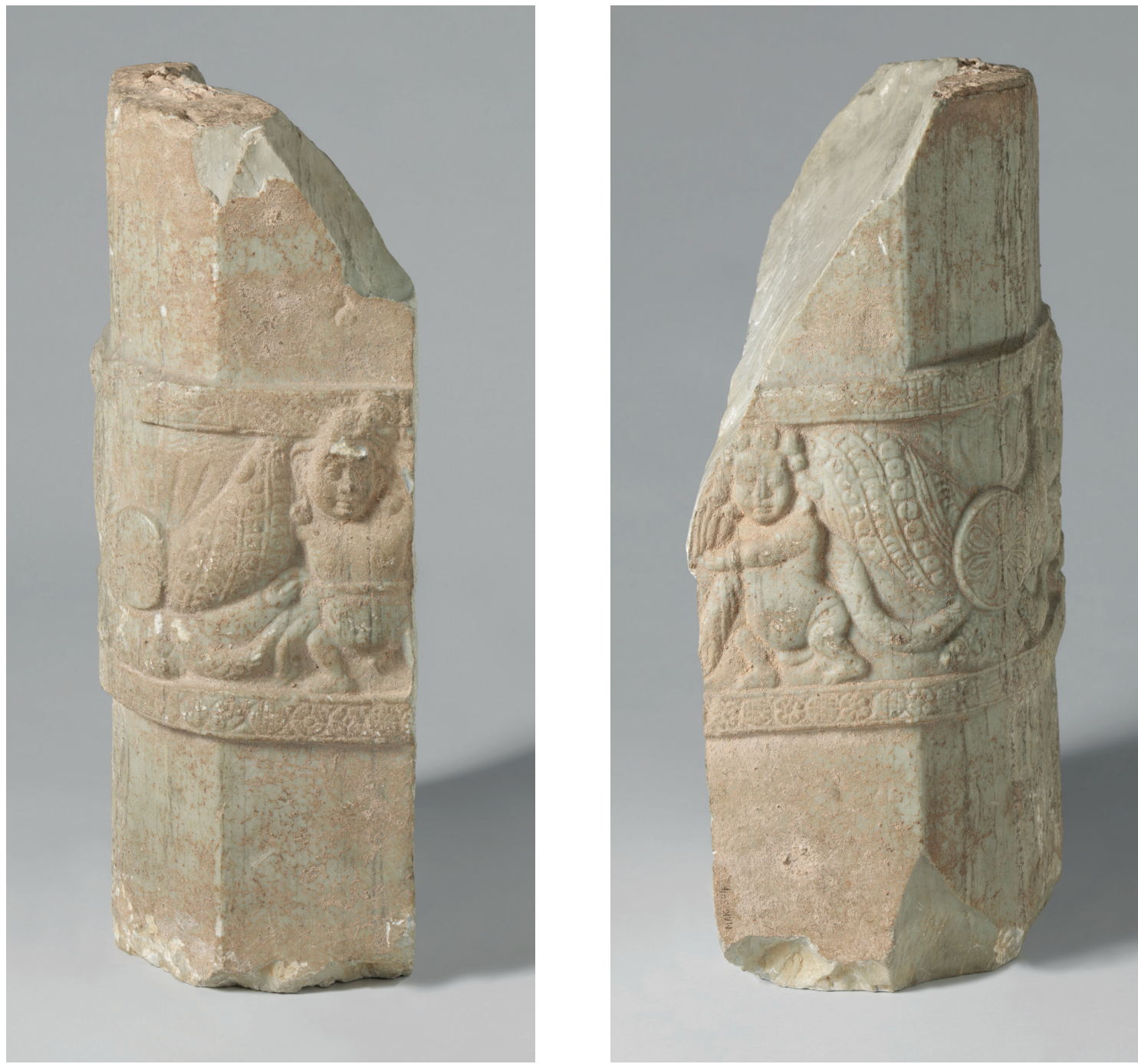

Fig. 2 (left)

Right side of Fig. 1

Fig. 3 (right)

Left side of Fig. 1
And yet, the ganas did not disappear altogether after the early period. We see them, albeit in miniature, on the dome of the stūpas depicted on drum slabs from Amaravati and Nagarjunakonda (fig. 4). Interestingly, such friezes were never employed in the actual decoration of the dome, but it is possible that the sculptures have not survived. Admittedly, these carvings are so small and eroded that it is sometimes difficult to determine whether the tiny figures represent dwarves or 'youths'. In many cases, however, they seem to be genuine ganas resembling those on our pillar. On the other hand, their postures are different: running rather than standing, with the frieze neatly contained within the ornamental border, while on the Amsterdam pillar it overlaps it. ${ }^{5}$ 
Fig. 4

Drum slab, Nagarjunakonda (detail), ca. zrd century, present location unknown. Photo: J.E. van Lohuizen-de Leeuw. Courtesy of Leiden University, Digital Special Collections, inv.no. P-006502

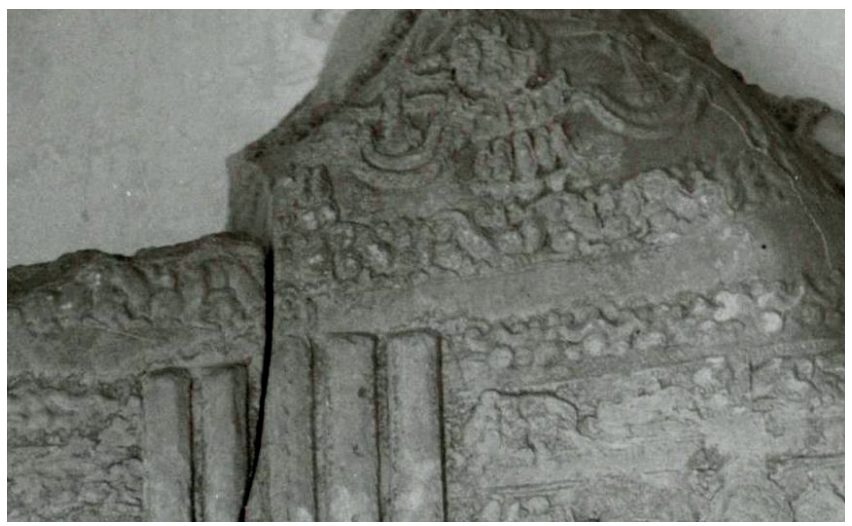

Fig. 5

Drum slab from Site 6,

Nagarjunakonda (detail), ca. 250, present location unknown.

After Rosen Stone 1994, fig. 124

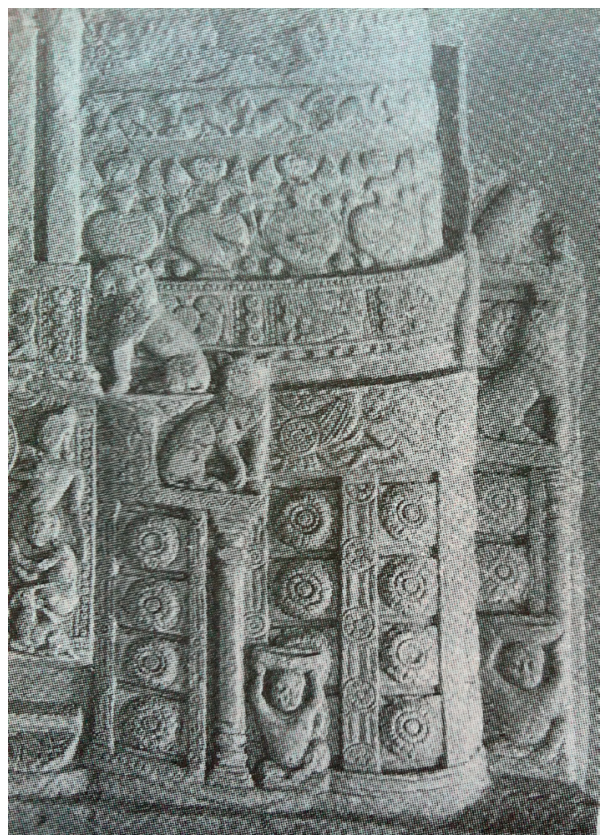

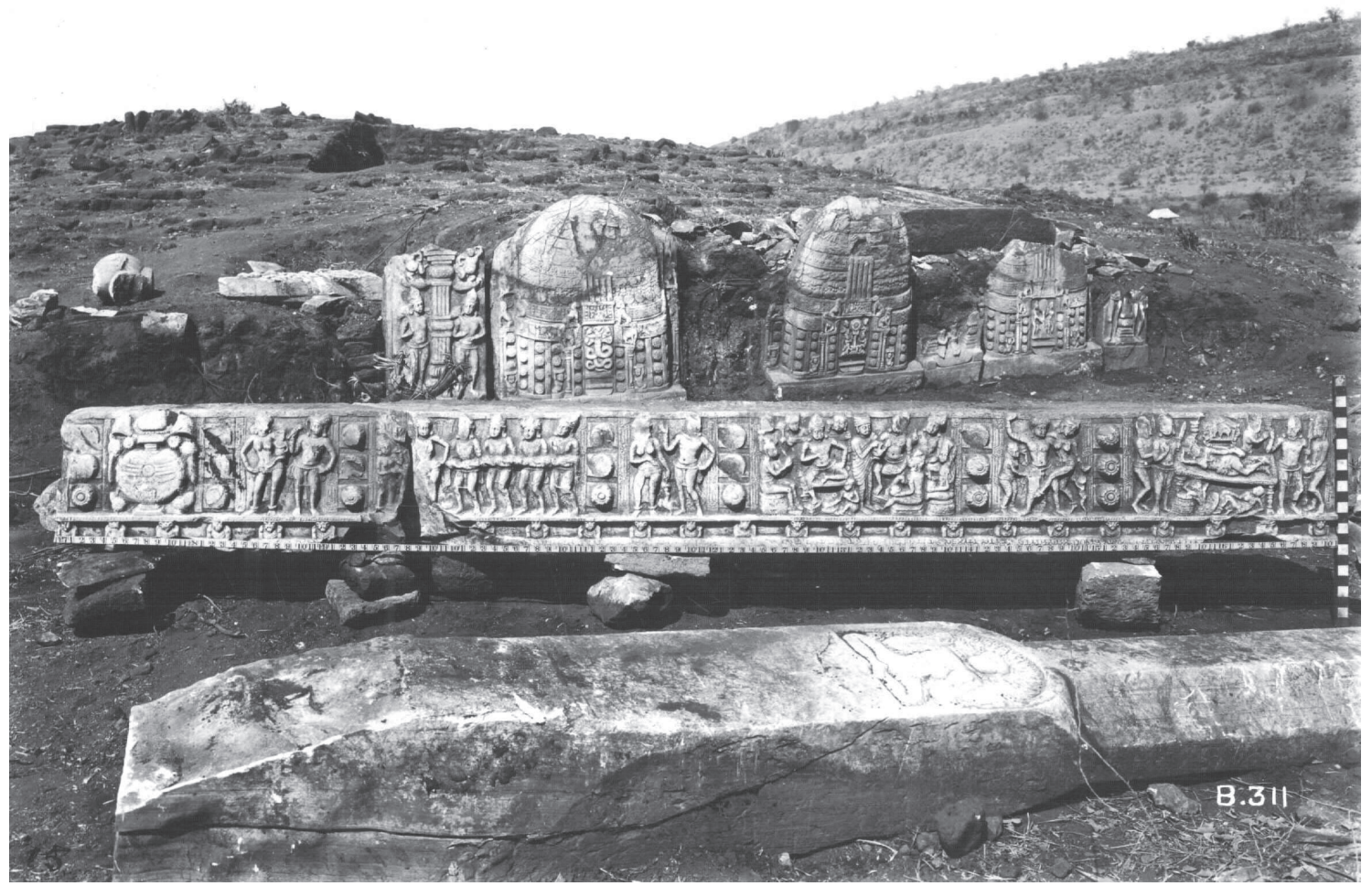

Fig. 6

Site 6, Nagarjunakonda. Photo:

Leiden University, Digital Special

Collections, inv.no. P-038041 


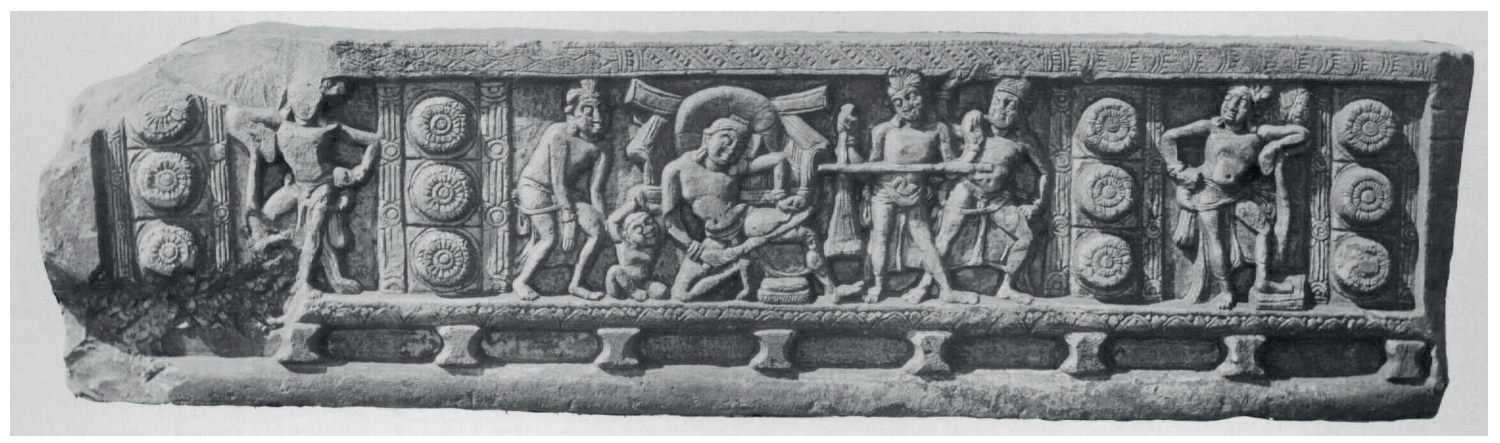

Fig. 7

Śibi Jātaka. Āyaka

panel from site Site 9,

Nagarjunakonda,

ca. 250, Archaeological

Museum,

Nagarjunakonda.

Photo: Leiden

University, Digital

Special Collections,

inv.no. P-oz8122
Among these small friezes is one that deserves special attention. It adorns a miniature stūpa on a drum slab and is carved not on the stūpa dome but, uniquely, on a rail coping (fig. 5). It comes from Site 6 in Nagarjunakonda and has been dated by Rosen Stone to the reign of Virapurusadatta (238262). ${ }^{6}$ Site 6 was amongst the first to be discovered and has therefore been poorly documented, but this sculpture's provenance is confirmed by a photograph showing it in situ (fig. 6, centre). Contrasting the miniature friezes discussed earlier, the thick garland here hangs at a similar angle to the Amsterdam one and is twisted such that the strings fall vertically. Furthermore, the lotus medallions each have eight petals and five tassels and the heads of the figures overlap the upper decorative border. Although the motif above the medallions is not a cup-shaped calyx, but an open lotus flower, the entire composition appears closer to that on the Society's pillar than the miniature friezes from Amaravati.

\section{The ornamental border}

Another element that might be of importance for determining the provenance of our pillar is the thin horizontal borders flanking the garland-and-dwarves frieze. Remarkably, the decoration on the top is not the same over the entire length of the border, but there are zones of different motifs, namely: leaves (overlapping in the fashion of fish-scales), half-moons or scoops marked with tiny horizontal grooves, and a twisted garland, each zone separated by uprights with rows of beads in between.

Contrary to what might be expected, borders of this type are quite rare. In ornamental horizontal bands, as a rule, a single pattern is used over the entire length. The only noteworthy exceptions are some panels from Site 9 in Nagarjunakonda where the upper ornamental border consists of a string of motifs, which are, moreover, similar to those on the Amsterdam pillar. The border on the panels illustrating the Śibi Jataka, for instance, has all three of the motifs noted above, also separated by vertical lines with dots in between (fig. 7). The leaf-pattern, the least common of the three, frequently consists of two leaves with the third one emerging between them. Yet, on another panel from Site 9, it consists of only two leaves plaited in a similar way as on the Amsterdam friezze.7 ${ }^{7}$ l. comø4/26/2023 11:40:50AM 
The lower border consists of a row of small 'cornflowers' alternating with circles filled with a chequered pattern. In this case, no identical border could be found, but such flowers and circles in combination with other motifs were popular during the zrd century and seem especially widespread on sculptures from Nagarjunakonda. The same holds true for the twisted garland, the cornflowers, the chequered pattern and the striated half-moons. ${ }^{8}$

Bénisti has already noted the importance of ornamental motifs for the study of Andhran art. Rosen Stone takes this further and ascribes an especially important role to the patterns bordering the narrative friezes, noting that such decorative borders are as a rule specific to the findsite. ${ }^{9}$ The fact that an ornamental border resembling that on the Amsterdam pillar is only found on sculptures from Nagarjunakonda Site 9 seems therefore significant.

\section{Tokyo}

It should be added at this point that the fragment in the Rijksmuseum amounts to five faces of what was originally an octagonal pillar, now lacking the upper and lower part of the shaft and split longitudinally. Uniquely, in contrast to numerous other examples of split-up pillars, here the missing 'back' has survived and could be traced. It is in the collection of the Tokyo National Museum, where it has also been attributed to Amaravati (fig. 8). ${ }^{10}$ The parts seem to match pretty well, with no missing fragments, as demonstrated by one of the Amsterdam dwarves whose severed left arm can be seen on the Tokyo fragment.

Fig. 8

Back of Fig. 1. Tokyo National Museum (TC-789). Photo: Anna Ślączka

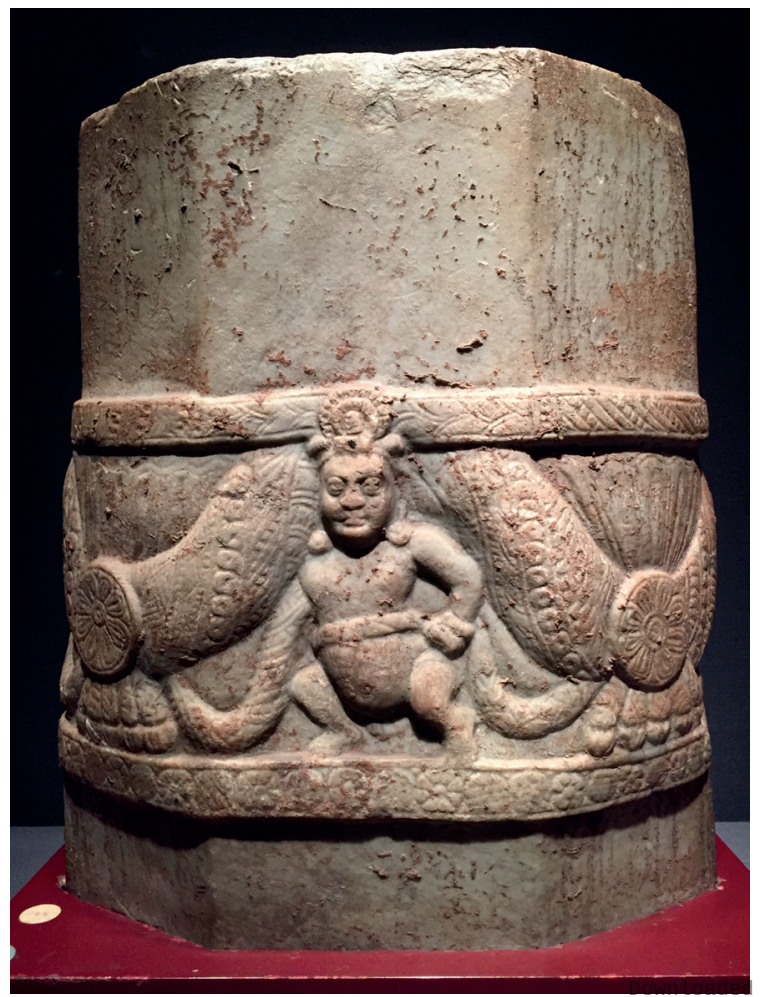




\section{Acquisition}

As already noted, the pillar fragment entered into the Rijksmuseum collection after the VVAK acquired it in I955. Only the seller is recorded in the Society's archive: the art gallery J.C. Moreau-Gobard in Paris. ${ }^{\text {II It }}$ appears however that in 1934 another Parisian art dealer, C.T. Loo, owned both parts of the pillar. ${ }^{12}$ Interestingly, soon after the acquisition of the first fragment, the Society learned of its counterpart and urged MoreauGobard to trace it. ${ }^{13}$ Although it was offered to the Society, the purchase was never finalised, likely for financial reasons. ${ }^{14}$ After travelling a long and convoluted route - between I977 and I983 it was apparently on loan to the Denver Art Museum and in I990 it suddenly appeared in a Sotheby's sale catalogue - the second part of the pillar eventually reached the Tokyo National Museum where it remains until today..$^{15}$

C.T. Loo's supplier of Indian objects was the self-taught archaeologist and art historian Gabriel Jouveau-Dubreuil (I885-I945), author of several publications on Indian art. The two men met in Paris between 1922 and 1923, after which Jouveau-Dubreuil returned to the French colony of Pondicherry in India as Loo's 'buying agent'. ${ }^{16}$ Over the following years he shipped numerous sculptures to France, among them Pallava and Chola images from Tamil Nadu and several early Buddhist pieces from Andhra that are now in European and American collections. He also supplied sculptures from Andhra to the Government Museum in Madras (present Chennai).

It is therefore quite possible that the Amsterdam pillar reached C.T. Loo via Jouveau-Dubreuil. In this regard it is interesting to note that JouveauDubreuil did visit Andhra in the relevant period, namely before I934. In I926 he even conducted a brief excavation of Nagarjunakonda's Site 6, and allegedly removed several sculptures. ${ }^{17}$ As demonstrated earlier, at least one sculpture from this site is carved with the garland-and-dwarves motif, very similar to that on the Amsterdam pillar. Also, reliefs from Site 9 show strong resemblances to the pillar in ornamental pattern, but this is only to be expected, for both sites belong to the so-called early Nagarjunakonda style and are close in date. ${ }^{18}$ No such similarity is found with reliefs from Amaravati.

\section{Attribution and date}

In view of the above, I believe that the previous attribution of the pillar to Amaravati is not convincing. Instead, there are good reasons to suggest that the fragment was collected from one of the earlier Nagarjunakonda structures, possibly Site 6 or 9. Of course, since no identical object has been found in Nagarjunakonda (or, indeed, anywhere else), the pillar could also be from one of the smaller sites stylistically close to early Nagarjunakonda.

The fact that the pillar seems to belong to the early Nagarjunakonda style also has implications for its date. The piece has been variously dated, from the ist century (Tokyo), through 'circa 2nd century' (Sotheby's), the 2nd3rd century (de Coral Rémusat), to the 3rd century (Yoged) I9 Cconsidering 11:40:50AM 
that the earlier discussed drum slab from Site 6 and the panels from Site

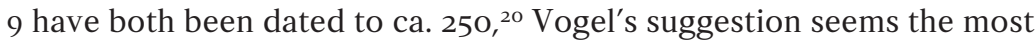
plausible. The pillar could therefore have been made somewhere during the reign of Virapurusadatta (r. 238-262).

We will probably never be certain where exactly the pillar came from, unless a similar sculpture is found. The piece is too fragmentary, leaving very few elements for comparison. And yet, this modest sculpture embodies a number of issues encountered by everyone who attempts to study Andhran art, and perhaps Indian art in general: poorly documented excavations and the subsequent loss of the archaeological data; but also advantages - these two fragments have survived, after all - as well as the dangers of an art trade driven by Western interest in Indian artifacts; and the importance of well-documented acquisition history.

- Dr. Anna Ślqczka is a curator of Indian art at the Rijksmuseum Amsterdam. She graduated in Leiden in the area of Sanskrit and Indian art in 20o6. Her main focus is on the connections between South and Southeast Asia, iconographic Sanskrit texts, art and architecture of India, and Hindu temple rituals.

\section{LITERAT URE}

Douglas Barrett, Sculptures from Amaravati in the British Museum, British Museum, London, 1954.

Mireille Bénisti and Philippe Stern, Évolution du style Indien d'Amarāvatī, Presses Universitaires de France Paris, I96I.

Mireille Bénisti, 'Nagarjunakonda. 'Essai de "caractérologie"', Arts Asiatiques 6 (1959), pp. 217-234.

Gilberte de Coral Rémusat, 'De l'origine commune des linteaux de l'Inde "Pallava et des linteaux khmers préangkoriens', Révue des Arts Asiatiques 8/3 (1934), pp. 242-250.

S. S. Gupta, Sculptures and Antiquities in the Archaeological Museum, Amarāvatī, D.K. Printworld, Delhi, 2008.

Padma Kaimal, Scattered Goddesses: Travels with the Yoginis, Association for Asian Studies, Ann Arbor, 2012.

Robert Knox, Amaravati: Buddhist Sculpture from the Great Stūpa, BM, London, I992.

Elisabeth Rosen Stone, The Buddhist Art of Nāgārjunakoṇda, Motilal Banarsidass, Delhi, 1994.

Christophe Roustan Delatour, 'Gabriel Jouveau-Dubreuil: l'érudit de Pondichéry', in: J.P. Desroches, E. Starcky and C. Gras (eds.), Âges et visages de l'Asie: un siècle d'exploration à travers les collections du musée Guimet, Dijon, 1996, pp. 3I-40.

Akira Shimada, Early Buddhist Architecture in Context: The Great Stupa at Amaravati (ca. 300 BCE - 300 CE), Brill, Leiden and Boston, 2013.

Jean-Philippe Vogel, 'Een belangrijke aanwinst van het Museum van Aziatische Kunst', Bulletin van het Rijksmuseum 3 (1955), pp. 5I-58. 
* Reviewed by Mark Poysden.

I Shimada 2013: 130 and Appendix B.

2 In addition to the literature search, I conducted a brief fieldwork trip to Andhra and visited, among others, Amaravati, Nagarjunakonda, Ghantasala, Bhattiprolu, Chebrolu, Guntupalli, Jaggayyapeta, Gummadidurru and Alluru. None of the sculptural remains seen thus far matches the pillar.

3 Dating by Shimada 2013: 99.

4 In some cases, the 'youths-frieze' is found on genuine coping stones. However, some stone fragments, carved on one side only and lacking the mortise hole on the bottom, were categorised as 'miscellaneous pieces' (Barrett 1954: 70; Shimada 2013: IIO) or as 'dome slab friezes' (Gupta 2008: pls. 3I-32), while Knox (1992: 98, I03) still speaks of them as 'rail copings'.

5 On only one relief do the dwarves seem to resemble those on the Amsterdam pillar, even though other details differ. Uniquely, the relief in question (ca. 20o250), which is a part of a decoration of a miniature stūpa depicted on a drum slab, is found to the side of the ayaka platform and not on the top of the dome (for an illustration, see Bénisti and Stern 196r: pl. xliv).

6 Rosen Stone I994: 5I-58 and fig. I24.

7 Leiden University Library, Digital Special Collections P-042934.

8 Bénisti 1959: 218-222 and fig. 30; Rosen Stone 1994: figs II9, 19I, 229.

9 Rosen Stone 1994: 87.

Io http://www.tnm.jp/modules/r_exhibition/index.php?controller=item\&id=3528\& lang=en (Accessed 28.08.2015).

II Moreau-Gobard writes about 'pilier d'Amaravati', while Visser, curator of the Society's collection, describes it as 'le fragment de Nagarjunkonda (?)'. See letters from Moreau-Gobard to Visser (undated, probably end 1954) and from Visser to Pierre Dupont (24 January 1955), VVAK Archives, Rijksmuseum, bands 70 and 80). I2 De Coral Rémusat 1934: pl. LXXIV.

I3 It was apparently Mrs. F.M. Minkenhof, herself a collector of Asian art and a member of the Society, who learned about the existence of the other part of the pillar and insisted on tracing it. At the time, the pillar was in the possession of an American private collector who had recently purchased it in Switzerland (VVAK Archives, band 9I, letter from Jan Fontein to Jean-Philippe Vogel, 26 October 1955).

I4 In the correspondence preserved in the Archives, Moreau-Gobard is described as a rather expensive art dealer; the price asked for the first fragment, 450,000 French francs, was considered very high indeed (letter from Visser to Dupont, dated 24 January I955, idem.). Eventually, the piece was bought thanks to external funding.

I5 Sotheby's Auction Catalogue, New York, October 1990, lot 6.

I6 Roustan Delatour 1996: 37; Kaimal 2012: 7, I37-I42.

I7 He removed them, 'before this site was classified among the ancient monuments selected by the Madras Presidency for conservation' and just before the trial excavation of this site by Hamid Kuraishi (Dimand 1928: 238).

I8 Rosen Stone 1994: 52.

I9 Vogel's short article (1955) was thus far the only one dedicated to the pillar. It should be noted that Vogel refuted both Amaravati and Nagarjunakonda as plausible findsites. His opinion, however, seems not to have been given much consideration, for the pillar is still labelled 'Amaravati' in the Rijksmuseum files. 20 Rosen Stone 1994: 5I-58. 


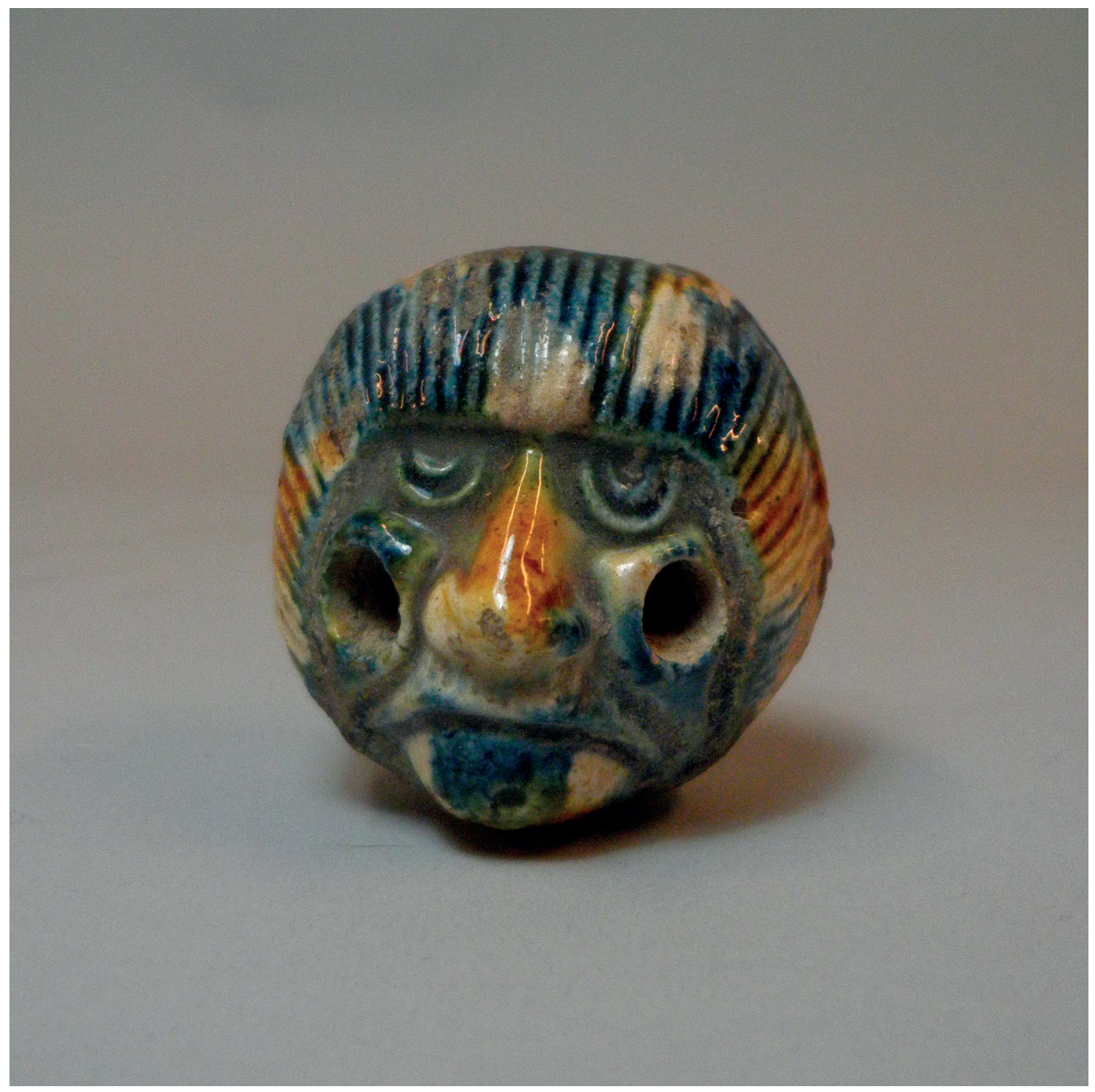

Afb. 1

Fluitje, kop van een

westerling, driekleurig

geglazuurd (sancai)

aardewerk, China,

Tang-dynastie (618-

907), h. 3,8 cm, (Nanne

Ottema Stichting)

Keramiekmuseum

Princessehof, Leeu-

warden, inv.nr. NO

01512. Foto: Eline van

den Berg 